\title{
'We pray you all ... to drink ere ye pass': Bann Criers, Parish Players, and the Henrician Reformation in England's South- east
}

Recent years have seen a critical reevaluation of the playing practices in medieval and early modern England. To claim that our understanding of early English drama has changed since E.K. Chambers published his monumental studies, The Mediaeval Stage and The Elizabethan Stage understates the case. While Chambers noted and recorded evidence of 'a vigorous and widespread dramatic activity throughout the length and breadth of the land', he understood this extensive activity as an aberration. ${ }^{1}$ Commenting that 'it is curious to observe in what insignificant villages it was from time to time found possible to organize plays', Chambers nevertheless assumed that the large cycle plays of York and Chester were exemplary of medieval drama throughout England and lamented that 'there were several important towns in which ... the normal type of municipal drama failed to establish itself'. ${ }^{2}$ This 'normal type of municipal drama' now appears to have been the aberration rather than the norm. As Alexandra Johnston argues, 'the major locus for the performance of religious drama in England before 1550' is now understood to have been 'not the cities but smaller towns and parishes'. ${ }^{3}$

Alongside this identification of the parish and small town as the 'locus' of religious drama, a reevaluation of the early Reformation's effects on these activities has emerged. The adaptations of the Chester cycle and the Digby Conversion of St Paul to a protestant context as well as the adaptations of biblical drama by evangelical writers such as John Bale and Lewis Wager testify to what Paul Whitfield White has identified as early reformers' 'more complicated, and often positive, interaction with civic biblical drama ... prior to 1580 '. ${ }^{4}$ Indeed, evangelicals decided quite early to put drama to their own use. Richard Morison advised the substitution of Robin Hood 'plaies' with new 'others ... dyvysed to set forthe and declare lyuely before the peoples eies, the abhomynation and wickednes of the bysshop of Rome, monkes, Freres, Nonnes, and 
suche like'. ${ }^{5}$ Yet Morison's advice extended beyond the writing of new 'plaies' as he also advised the adaptation of local festivities to celebrate Henry VIII's victory over Rome: yearly feasts should be held, annual triumphs and bonfires should be made, a yearly holiday ritual modeled on the Coventry Hocktide festivities should be instituted, and on at least one day each year the evils of Rome should be preached. ${ }^{6}$ As Robert Hornback argues, early reformers took up Morison's advice and set to work adapting local celebrations of misrule to their purposes. ${ }^{7}$ Early evangelicals thus had a broad sense of the 'plaies' they hoped to adapt, a sense that included processions, pageants, and games. Very often small towns and parishes were the location for the performance of such 'plaies,' and in 1539 the French ambassador Marillac commented on widespread expression of anti-papal sentiment in England, noting that 'there is not a village feast nor pastime anywhere in which there is not something inserted in derision of the Holy Father'. ${ }^{8}$

Despite Marillac's claim, not all pastimes were adapted to include antipapal sentiment or evangelical misrule, and some, particularly the more elaborate or spectacular 'plaies', disappeared. In the Thames Valley, for example, the last recorded Easter play at St Laurence, Reading play took place in 1538 while the last at Thame was performed in $1539 .{ }^{9}$ Throughout the diocese of Canterbury, a tradition of parish and borough 'plaies' that had thrived since the early fifteenth century came to an abrupt halt in the mid-1530s, as did, albeit at a slightly slower pace, similar traditions throughout England. ${ }^{10}$

While the growing critical significance of religious drama's performance in small towns and parishes compels critical study of the geographical, material, and cultural specificity of such performance, the critical study of evangelical adaptations of religious drama demands an account of the apparent failure of many small towns and parishes to adapt their performance of religious drama or 'plaie' to the context of the Henrician Reformation. This failure to adapt has been identified as the result of an evangelical suppression of traditional devotional practices. ${ }^{11}$ Yet another account of the effect of the early part of the Reformation on this drama is possible. While he implies a connection between the Reformation and the sudden decline of parish 'plaies' from their 'height in the 1520s', John Wasson sees the causal relationship between the two events in more ambiguous terms, particularly because documentary evidence of an explicit suppression is lacking. ${ }^{12}$ The coincidence of the decline of such locally-produced 'plaies' with the beginning of the Reformation thus appears suggestive but hardly conclusive of a doctrinally-motivated suppression of such activity. 
In this essay I contextualize the apparent non-adaptation of both parish religious drama and parish 'plaies' in the 1530s by examining the playing history of New Romney and Lydd, two Kent towns in the diocese of Canterbury. These towns had a lengthy tradition not only of mounting plays - New Romney's was a passion play and Lydd's a St George play — but also of contributing money to the support of each other's as well as the 'plaies' of nearby towns. In particular I focus on the decline in rewards paid by several towns throughout the diocese and parts of Sussex to bann criers and other parish performers and argue that the almost complete disappearance of bann criers and performers from these towns during the 1530s does not signal an evangelical suppression of this activity. Rather, the decline evidenced in the early 1530s is but the tail end of a decline which had begun in the late-1520s.

As I have slipped in the discussion above from a consideration of parish and town religious drama to one of parish 'plaies', I will comment on the distinction between the two. As Lawrence Clopper argues, a degree of critical caution must attend interpretation of evidence of early modern 'playing'. The various terms employed in the records - variations of 'pley' or 'ludi', for example - require an interpretation capable of distinguishing between play (in the sense of a dramatic script or the performance of one) and 'ludi' (in the sense of game or, for example, ritual celebrations of misrule). According to Clopper, the records in many cases lack sufficient clarity for scholars to differentiate between the two, and Clopper adopts a vocabulary which carefully distinguishes between the playing of a certain dramatic script (which requires evidence of such a script) and the playing of an entertaining spectacle. With 'plaies', I have in mind what Clopper calls a 'ludus': 'a civic, or more likely, a parish entertainment, a spectaculum, whose purpose is to raise funds. Such entertainments might include scripted plays about the patron saint or some other saint; however they might simply be sports, contests, amusements, pageants, or any combination of these'. ${ }^{13}$ Throughout this essay, I employ 'ludus' to refer to an entertainment for which evidence is lacking to determine the entertainment's precise nature.

In addition, Clopper describes 'ludi' in terms of their social function. These parish-level activities

bring together groups of people in an untypical relationship that fits, in general, Turner's sense of communitas, that is, one of those anti-structural situations in which there is a greater degree of equality than usual and that has the effect of renewing the society that it temporarily abandons. The parish ales seem to be 
fairly simple relaxations of social structures for recreational purposes and economic gain. ${ }^{14}$

Clopper goes on to differentiate the parishes' desire for money from the acknowledgment of the greater Christian community, noting that 'Opening the parish up to outsiders - even though motivated by the desire for money - acknowledges that there is a larger Christian community. ${ }^{15}$ Yet the giving and the receiving of money signify two important things. First, the giving and gathering of money mark the participation of both insiders' and outsiders' membership in that greater community. While it may have been motivated by material concerns, the giving and the collection of money functions as a material expression of 'communitas'. As Marjorie McIntosh argues, events such as parish ales and 'ludi' were organized by local institutions, and participation in these institutions and their activities 'generated social capital that was of use not only to their own members but also to the broader community'. ${ }^{16}$ Such social capital 'included the creation of personal networks based upon respect, trust, and shared experience that comprised people beyond their own families, immediate neighbors, and personal friends'. ${ }^{17}$ This social capital also could flow across parish or county boundaries and included the promotion of 'shared norms and a conception of the public good' and also 'built more far-reaching social, institutional, and ideological bridges' with neighbouring communities. ${ }^{18}$

The second significance of the giving and collection of money is that these activities often were recorded and have become part of the historical record of 'communitas' and of the generation of social capital. While recognizing the 'inherently difficult' nature of studying social networks, McIntosh argues that 'we must look for indirect signs of their existence in historical sources and literary texts', suggesting that we may identify the creation of such networks through the study of 'social and economic interactions'. ${ }^{19}$ Noting that 'Acts of gift giving or puchasing prized goods carry weight precisely because they are described and accepted as virtues in their own right', McIntosh thus argues that in the absence of more detailed evidence, the generation of social capital can be studied by paying attention to particular economic transactions, such as the rewards paid to bann criers and other parish performers, which signify an exchange in which social capital is at stake. ${ }^{20}$

The symbolic value of money paid not only to attend a play but also to prepare a play for performance is exemplified by an incident in 1560 which pitted, in the mind of one of the participants at least, a play planned 
by John Bale against the 1560 New Romney passion play. In this case the incident made its way to court where the principals and witnesses gave their depositions, which survive in the consistitory court records, and the description below is based on the depositions given to the court. ${ }^{21}$ On Friday, 24 May, Hugh Pilkington, a tailor, asked his loitering servant, Phillip Hall, to return to work: not only did a woman's gown require sewing but a player's garment - a friar's coat - also required more work. Richard Okeden interrupted the men's conversation, reportedly saying to Hall, 'Godys blode thow arte my contry man ... if thowe make a fryers cote thowe shalte be my contry man no more.' He offered two pence towards Hall's dinner if Hall refused to make the garment. Okeden then asked whether the play was Mr. Bale's doing, and Pilkington answered that it was: a play would be performed at Mr. May's house and one of the characters would wear the friar's coat. Noting that Bale and May were 'rych enough already,' Okeden asked whether they would collect any money at the play. Not waiting for an answer, Okeden vowed to attend but immediately changed his mind, exclaiming, 'goddes blode I will not com there I will goo to Romeny wher ther is good play'.

Okeden's reaction suggests a knot of loyalties tied not so much to the performance of May and Bale's play as to the social value of the money set into circulation by it. Not only did he object to the presumed stridency of the play, but he also objected to the alleged financial motivation for staging it: May and Bale were 'rych enough already' and according to Okeden had no acceptable reasons for gathering money at the play. Moreover, the monetary transactions marked the establishment of social credit for Okeden. By offering to pay Hall, Okeden attempted to validate their present bond as countrymen by extricating Hall from his participation in Bale's play. Even more importantly Okeden understood the payment for attendance at either play as signifying a particular social relationship. The description of the New Romney play as a 'good play' emerged from his objection to the use of the money gathered. Whereas Bale and May, in Okeden's view, were motivated by private profit, the New Romney play, produced by the New Romney chamberlains, was motivated by a more laudable concern.

Okeden's vociferous objection resonates with the implicit attack answered by one of Bale's contemporaries, Lewis Wager. The prologue of Wager's midsixteenth-century Life and Repentaunce of Mary Magdalene defends the performers of that play against charges similar to those made by Okeden: 
O (they say) muche money they doe get.

Truely I say, whether you geue halfpence or pence,

Your gayne shalbe double, before you depart hence.

Is wisedom no more worth than a peny trow you?

Scripture calleth the price therof incomparable.

Here may you learne godly Sapience now,

Which to body and soule shal be profitable.

To no person truly we couet to be chargeable,

For we shall thinke to haue sufficient recompence. ${ }^{22}$

Wager's prologue clearly does not assume the legitimacy of the players' profit but instead defends it on the grounds that the content of the play provides something of value in exchange for the audience's money. The exchange, moreover, is a fair one although the prologue subtly suggests that the audience receives the better value in the exchange and might thus consider offering a penny rather than halfpence. What the audience has paid for, then, is profitable to individuals: financially so for the players, and spiritually so for the audience members.

Wager's defense of the players' profit, however, differs from the plea for money and implicit defense of profit made by the epilogue of a now lost fifteenth-century parish play. After thanking the 'wursheppful soueryns pat syttyn here' for having witnessed the play in 'soferyng sylens' and 'withowte ony resystens', the epilogue entreats the audience to spend its money at the ale following the play:

We pray zou alle in Goddys name

To drynke ar ze pas;

For an ale is here ordeyned be a comely assent

For alle manner of people pat apperyn here pis day,

Vnto holy chirche to ben incressement

All that excedith pe costys of our play. ${ }^{23}$

Whereas Wager's prologue defends the money earned by the players in terms of the value to individual audience members of the play's 'wisedom', the Reynes epilogue plays to a concern for the church's welfare by assuring the audience that the money raised by the play and at the ale will cover only the expenses laid out to perform the play. Any money gathered in excess of those costs will go towards the 'holy chirche'. The profit of the play, 
according to the epilogue, will remain in and, more importantly, benefit not only the parish's material church but also the universal, immaterial 'holy chirche'.

Okeden's response to Bale's proposed play can be better understood in light of these two defenses. That is, Okeden's response is a complicated one which registered more than his reaction against the play's content or his personal animosity towards Bale. Indeed, Okeden's response suggests the way in which early modern plays could occasion strong personal response based on religious affiliation but articulated through an understanding of those plays not only in terms of their content but also in terms of their operation as a social and economic practice. As Okeden understood, then, the staging of a play made claims on a local community even before the play's performance, and these claims were signified by the financial transactions occasioned by preparations for and attendance at the play. Social networks could be signified by as little as the offering of twopence for dinner.

Yet Okeden's response signifies as historical record as well. While no evidence demonstrates that New Romney staged its play in order to raise funds for specific capital projects, clearly the net loss of $22 \mathrm{~s} 91 / 4 \mathrm{~d}$ generated by the play came out of the town's coffers. ${ }^{24}$ The play wardens' accounts of the 1560 New Romney play record receipts not only from nearby parishes' contributions but also from the audiences which attended the four performances of the play. While we cannot know whether Okeden witnessed this 'good play', the records of the money gathered offer evidence of the production of 'communitas' and the generation of some form of social capital.

Ludic events similar to the New Romney play often were performed in England's south in order to raise funds for a unique or particularly expensive capital project such as major repairs to the church or the purchase of items such as bells or saints' statues. ${ }^{25}$ As early as 1428 the Glastonbury parish of St John's performed Christmas and Midsummer 'ludi' in order to help defray the parish debt. ${ }^{26}$ Five Tintinhull parishioners performed a 'Christmasse pley' in 1451, and the $6 \mathrm{~s} 8 \mathrm{~d}$ they raised may have helped purchase a new rood screen. ${ }^{27}$ Two Thames Valley parishes, St Laurence' Reading and St Mary's Thames, staged several biblical plays in the late-fifteenth and early-sixteenth centuries to raise funds. ${ }^{28}$ The parish of Stortsford in Hertfordshire raised money not only by staging five plays between 1490 and 1532 but also by renting props to other parishes. ${ }^{29}$ In order to pay for substantial repairs to the church porch, the Boxford churchwardens staged a play in 1535, raising close to $£ 19$ even after the 'propyrte player' and 'dyverse pleyers which cam owt 
of strange placys' had been paid respectively 30 s and $15 \mathrm{~s} .{ }^{30}$ Although how much money it made is unclear, the Cambridgeshire parish of Bassingbourn staged a St George play in 1511 as part of its fundraising for the purchase of a St George statue, but the play appears to have been among the less lucrative fundraisers the parish undertook. ${ }^{31}$

After having practically disappeared during the latter years of Henry VIII's and Edward VI's reigns, the organization of such events began again in the mid-1550s. Parish or borough 'ludi' continued to be viewed as sources for funds during this revival. In part this revival may have been spurred by the ecclesiastical authorities' interest in restoring neglected churches, to say nothing of those that had been defaced or otherwise damaged during the iconoclasm of the 1530s and 1540s. Nevertheless, the capital projects for which funds were raised also extended to secular projects. In 1562 the profit from a play staged in Sandon, Essex, went toward the reconstruction of a bridge, and an early 1560s play staged in Donington, Lincolnshire, perhaps funded the repair of a local dike. ${ }^{32}$ Such plays, however, were not always financially successful. A series of plays in Chelmsford, Braintree, and Maldon in 1562 did not earn enough money to repay a $£ 4$ loan that the Chelmsford churchwardens had solicited in order to mount the play. Instead the lender, Myles Blomefield, kept some of the town's costumes and its playbook which we may know now as the Digby manuscript. ${ }^{33}$

These fundraising 'ludi' could also become the occasion for conflict. In 1500, the parish of Pulloxhill sued a man in Chancery court for the money he had gathered and kept at a play he had staged ostensibly in order to raise money to repair the church. ${ }^{34}$ At times, such conflict arose less from fraudulent intentions than from simple misunderstandings. As a consequence of the 1535 Boxford play, a Peter Fenn was obliged to pay 26s 8d to the parish over the subsequent three years. As the churchwardens noted in the accounts that all gatherers of money for the play were to provide, at their own expense and without reimbursement by the parish, 'mete $\&$ drynk' for the out-oftown audience, Fenn apparently had kept the money in order to cover his own expenses for entertaining the audience from Neyland. ${ }^{35}$ The gatherers of money, then, were expected to front a considerable amount of money themselves in order to provide food and drink to the audiences from various towns.

As the Fenn misunderstanding suggests, the funds raised at these events were not drawn solely from the parish or town in which the plays were performed (although Fenn would likely have disagreed). While Coldewey iden- 
tifies three means by which communities raised funds for these plays - by subscription, by borrowing, and by charging admission - it is clear from the Boxford 1535 play and that these methods were not always distinct. ${ }^{36}$

Often towns and parishes participated in a network of contributions, contributing to each others' 'ludi' when they were performed. Robert Wright has identified a number of networks in Essex. ${ }^{37}$ For example, Great Dunmow's annual Corpus Christi celebrations, which often included a play, received financial contributions from twenty-five communities although not all communities contributed every year. ${ }^{38}$ Twenty-seven parishes contributed a total of $£ 319 \mathrm{~s} 10 \mathrm{~d}$ to the Bassingbourn St George play. 39 The organizers of plays in 1530 and 1532 in Heybridge, Essex, gathered money from twenty-three nearby towns. ${ }^{40}$ The 1535 Boxford play gathered money from twenty-six neighbouring towns. ${ }^{41}$ Diarmaid MacCulloch suggests that the towns contributing to Boxford's play were also ideologically united, as the list of contributing communities shows 'considerable overlap with the group of parishes which were at the centre of the Amicable Grant protest ten years earlier'. ${ }^{42}$ In turn these towns reciprocated by financially supporting their contributing communities' fund-raising activities. The Great Dunmow churchwardens gave money to several May events in surrounding villages, and the Boxford churchwardens made two disbursements to bann criers from another town, Stoke-by-Nayland. ${ }^{43}$

In many cases, the town and the parish were co-terminus not merely in administrative terms. ${ }^{44}$ While it raised money for the parish church, the 1535 Boxford play also figured in the minds of the parishioners as a town play. The memorandum dealing with Fenn's withholding of receipts refers to the gatherers not as parishioners but as 'persons of the towne' and notes the contributions not from other parishes but from other 'townshippes'. ${ }^{45}$ Some parishes not only shared the same boundaries as the towns in which they existed but also the responsibility for plays such as those discussed above. ${ }^{46}$ These plays, too, reflected a distinction between the wealthy civic elite and those who were not as wealthy: James Gibson and Isobel Harvey have correlated the local contributors to the New Romney 1560 Passion play with the tax assessments of the town's population and have shown that the funds for the play were provided largely by the town's wealthy elite. ${ }^{47}$

Although parish or borough 'ludi' probably (but not always) were staged on a smaller scale as entertainment at the regularly held ales, spectacular plays such as New Romney's were but an occasional element of parishes' fundraising activities. The large productions were underwritten by the intention, in 
the words of the Reynes epilogue, 'vnto holy chirche to ben incressement', and such 'ludi' secured outside financial assistance in order to further the communities' collective responsibility to the church. To a degree, these plays made this ethos of collective responsibility spectacularly visible not only to the producing communities but also to their audiences. These audiences, moreover, participated in the collective responsibility of the local communities, and the audiences for these plays included not only the individuals who attended the plays' performances but also the communities whose churchwardens or chamberlains had contributed money to the play. As the Reynes epilogue suggests, the 'incressement' of the church relied on - was the responsibility of - those with money to spend as much as the producers of such events. The donation of funds to these 'ludi' - either collectively by parish or borough representatives or individually by individuals paying to attend these events - marked donors as, in Okeden's term, 'country men'. Where affiliation and social credit is not explicit in the records of these 'ludi', they are implied by the records of the financial transactions among parishes, boroughs, and individuals. Such plays thus expanded their communities' boundaries by extending participation in their collective responsibilities to other communities.

The practice of parish and borough entertainment was similar in the diocese of Canterbury, particularly in south-western Kent. Much evidence of this activity in the sixteenth century survives in the borough accounts of Lydd, New Romney, and Rye, Sussex. While these accounts are reasonably continuous during 1500-75, the Lydd Chamberlains' accounts lack accounts for two periods relevant here, 1485-1511 and 1542-9, and the Rye Chamberlains' accounts lack 1570-1. ${ }^{48}$ The Dover Chamberlains' and Wardens' accounts also are rich. The Dover accounts, however, make it clear that parish and borough performances were rewarded at a substantially lower rate than in the other towns.

Based on the extant records, New Romney and Brookland appear to have been the most active in staging parish 'ludi', but several other parishes staged plays or 'ludi' as well. At Bethersden, the St Margaret's Churchwardens' accounts include evidence of receipts from a 'pley' performed sometime in or before 1520-1 and of a 'lude beate Cristine' performed in 1522. The accounts for the 1522 'lude' are fairly extensive while the 1520-1 account reports a profit of $£ 25 \mathrm{~s} 6 \mathrm{~d}$ from receipts collected on three different 'pleye daye[s]'. A clerk was paid 5s for 'Wrytyng', and a 'devyser' received $£ 310 \mathrm{~s}$ 'for his labor', and the work of these two individuals suggests this 'lude' to be 
a play, complete with script. The 'devyser' apparently came from outside the town as William Glover was paid 3s $4 \mathrm{~d}$ 'for carrynege vp and down of the devyores gere'. ${ }^{49}$ No other records of ludi or plays are recorded in the St Margaret's Churchwardens' accounts but bann criers and players from Bethersden were rewarded several times by other parishes. ${ }^{50}$

Another 'ludus' was performed in 1535 at Boughton under Blean: the Sts Peter and Paul's Churchwardens' accounts record receipts totaling $£ 45$ s10d, collected by 'stevyn Wylles ... for the fyrst play day'. An Edward Songer added a note to the record in 1578 that he 'was one hole yere old whan Corpus Christi play was playd in Boughton strete'. ${ }^{51}$ As well during the fifteenth century and early sixteenth century, bann criers from Hythe received rewards from various towns, but the nature of the 'ludus' they adverstised remains unclear. However, players from Hythe were rewarded for performing some form of Robin Hood activity in the sixteenth century.

Lydd appears to have performed a St George play as early as 1456, when the play was performed for 'Sir Thomas Keryell the luetenaunt of the Castill of douorre and her wyvys'. 52 'The Rye Chamberlains' accounts note that (between 28 March and 24 June 1456) 6s.8d. was given to 'men off lede when they shewyd her play', and in 1456-7, New Romney Chamberlains' accounts report 13 s given to 'lusoribus de lyde'. 53 In 1520-1, the Lydd chamberlains paid Thomas Buntyng $4 \mathrm{~s}$ 'for the boke of the pley of Saynte George the which he said that he wrote hym selfe' in addition to 11 s $6 \mathrm{~d}$ to one Bosom 'for brengyng of the seid boke of Saynte Georgis pley in to the Custody of the towne ageyne where as it was in the kepyng of other men'. ${ }^{54}$ In 1526-7, they paid 2s $4 \mathrm{~d}$ 'for a new Booke for the lyfe of Saynt George' and began a series of consultations which continued over the next few years with Richard Gibson concerning the performance of the play, which finally occurred in $1532-3.55$

Largely due to the survival of several records which provide tantalizing information about the play's nature, the New Romney passion play is the best known of the Kent 'ludi' ${ }^{56}$ A resurrection play existed as early as 1456-7 as in that year an entry in the New Romney Jurats' record book notes a dispute between the play wardens and another man over the play accounts. 57 Detailed accounts of two plays performed sometime between 1483 and 1486 survive, including payments and receipts noted for their performance. These two plays still treated Christ's resurrection as both plays required the construction of both heaven and hell stages. While a field appears to have been mown for the performance of the play in or near New Romney, a partially 
destroyed entry suggests that a wagon may have been hired to take the first play to Hythe. After the expenses had been paid, the play netted a profit $2 \mathrm{~s}$ $6 \mathrm{~d}$, with the largest share of the revenue collected at the plays. As well, bann criers collected funds from five nearby parishes and possibly from six individuals. ${ }^{58}$

The New Romney bann criers announced the play in advance of its performance, and the Chamberlains' accounts record a decree that the bann criers should cry the banns before the next feast of St George; if they failed to do so, the bann criers would be imprisoned for forty days. ${ }^{59}$ On 6 May 1517 the Lord Warden of the Cinque Ports ordered the New Romney play wardens not to perform the play until they received a license from the king to do so. ${ }^{60}$ As New Romney bann criers received a reward from the Rye chamberlains between 12 April and 24 June of that year and possibly from the Lydd chamberlains, it is unclear whether the play wardens obtained the license and proceeded with the performance of the play or whether they cancelled the performances despite having already cried the banns. ${ }^{61}$

In 1556 the town aborted a planned performance of the play, and in 1560 it successfully mounted a four-day performance. ${ }^{62}$ Again, most of the play's revenue was collected from the audience at the four different performances of the play; three of the performances were on Whitsun Monday, 14 June, and 4 August. While the banns were cried at Tenterden and Hythe, only Ivychurch and Lydd gave money towards the play. Lydd also rented or sold costumes to New Romney and received $£ 5$ for them.

By 1560 , the play had become more elaborate, requiring several additional stages to built. In addition to heaven and hell, the play required stages for Annanias and tormentors, for the Pharisees, for Herod, and for Calvary. Despite the large amount of money raised at the performances, the play lost $£ 12$ s $91 / 4 \mathrm{~d}$. ${ }^{63}$ The final mention of the play is a 7 March 1568 decree that 'all the playeres or the moste parte of them' as well as a Peter Welsh enter into bond to perform the play; if they fail to do so 'every player having partes shall presently surrender [them] ... \& so to be no more spoken of, or any more repeticion $\&$ rehersall thereof had $\&$ made'. ${ }^{64}$

The New Romney play appears to have been exceptional not only in terms of its scale but also in terms the regularity with which it was performed. In addition to the evidence of preparation or performance discussed above, rewards made to New Romney bann criers by other parishes suggests that the play was performed approximately every seven or eight years: in 1503, 1510, 
1517 (possibly), 1526, 1532-3, 1540, 1547-8, and 1560. Preparations for a play were aborted in 1556, and another play may have been staged in 1568 .

New Romney appears to have been the main participant in a network of Kent parishes performing 'ludi'. The surviving late-fifteenth-century New Romney play warden accounts record that $£ 14 \mathrm{~s} 10 \mathrm{~d}$ was collected by New Romney's bann criers from five nearby parishes: Ivychurch, Folkestone, Hythe, Lydd, and Brookland. ${ }^{65}$ While no records from these towns indicate contributions to New Romney bann criers between 1483 and 1485, the 6s $8 \mathrm{~d}$ each contributed by Lydd and Hythe appears to have been the customary amount donated by these towns to New Romney.

Each of these five contributing parishes had some form of 'ludus' of its own, and the number of entries in the Dover, Lydd, New Romney, and Rye accounts reporting rewards paid to bann criers indicates that the five most active Kent parishes that toured bann criers in the sixteenth century were these five contributing parishes. Evidence reveals that Brookland bann criers toured at least six times in the first three decades of the sixteenth century. Evidence also indicates that Lydd bann criers toured three times, Folkestone's and Ivychurch's twice, and Hythe's once. In addition to these, the bann criers of four other parishes received rewards: Appledore, Bethersden, Elham, and Halden.

Often, the years in which bann criers appeared can be fixed with some specificity. The Rye accounts divide expenses into four quarters, and we can determine when rewards were paid. The New Romney Chamberlains' accounts begin and end on 25 March in any given year, and the Lydd Chamberlains' accounts begin and end on 22 July. Thus, for example, the Rye accounts record a reward to Brookland bann criers between 12 April and 24 June 1506 while the New Romney accounts record a reward to Brookland bann criers between 25 March 1506 and 25 March 1507. It seems likely that these two entries refer to the same group of performers traveling to these towns sometime in the late spring or early summer of $1507 .{ }^{66}$ Similarly, the Rye accounts record a payment to New Romney players between 20 April and 24 June 1511 while the New Romney accounts record a reward to Brookland bann criers between 25 March 1511 and 25 March $1512 .{ }^{67}$ In addition, the Dover Wardens' accounts for 8 September 1510-8 September 1511 record that $3 \mathrm{~s} 4 \mathrm{~d}$ was 'gevyn to players of Brokland for the Reparacions of the Church ther'. ${ }^{68}$ Similar evidence shows that Brookland bann criers toured in $1519,1521,1527$, and $1534 .{ }^{69}$ Brookland players also performed during the 1517-18 winter at Lydd and Rye, and again at Lydd in 1521-2.70 
Moreover, the bann criers from these parishes received customary amounts from the other parishes' chamberlains. The customary reward paid to Brookland bann criers by both New Romney and Lydd appears to have been $5 \mathrm{~s} .{ }^{71}$ The customary amount paid by the New Romney Chamberlains to Lydd and Folkestone bann criers was $6 \mathrm{~s} 8 \mathrm{~d} .{ }^{72}$ While evidence indicates only that Brookland organized a 'ludus' 'for the Reparacions of the Church ther', these customary amounts contributed to the funding of the plays or 'ludi'. ${ }^{73}$ Lydd and Hythe contributed 6s 8d each to the 1483-6 New Romney play, an amount customary for the chamberlains of each town to reward New Romney bann criers. Of the ten contributions to New Romney 'lusoribus', players, or bann criers recorded by Lydd Chamberlains in the fifteenth century, seven of them are of the amount $6 \mathrm{~s} 8 \mathrm{~d}$, as are three of the five rewards made in the sixteenth century. ${ }^{74}$ Likewise, the Hythe Town accounts record that amount given to New Romney 'lusoribus' and 'Banecriers' in 1490-1 and in 1503-4. ${ }^{75}$ While no records of Lydd or Hythe contributions exist in those town records, it seems likely that they contributed their customary amount to the New Romney play. In 1560 the New Romney bann criers clearly passed along the 10s they received from the Lydd chamberlains as the New Romney play warden accounts record a contribution of 10 s from Lydd. ${ }^{76}$ One of the roles of the bann criers, then, was to collect money which would help fund the performance of the play.

The five contributing parishes listed in the play wardens' account of the 1483-6 New Romney play, moreover, all lie within twenty kilometers of New Romney although Brookland, Ivychurch, and Lydd are much closer, lying within eight kilometers of New Romney. ${ }^{77}$ The proximity of these parishes, the recurrent appearance of their bann criers (and players) in the Lydd and New Romney Chamberlains' accounts, and the graduated scale of customary rewards to bann criers suggests that parishes formed a network in which each parish contributed funds to the 'ludi' of the others. At the very least, these contributions marked a degree of reciprocity among these towns as each reward of bann criers became effectively parish revenue. At times, as with the 1511 Brookland 'ludus', these contributions were ear-marked for material reparations to the parish church. The expenditures on the entertainment of the bann criers suggest too that visits by the bann criers were occasions of festivity through which towns and parishes acquired social capital. In addition, the amount of money collected over the several days of the 1483-86 and 1560 New Romney plays as well as over the 1521-2 Bethersden 'ludus' suggests that the 'ludi' and plays themselves gathered large audiences, offering 
these parishes' inhabitants the opportunity to establish or maintain connections with those who lived distant from them. Indeed, a 1528 decree by the Lord Warden of the Cinque Ports banned all manner of performances for fear of the large audiences which would attend them. On 3 June 1528, the Lord Warden decreed that 'noo maner of stage pley Robyn hoodes pley wacches or wakes yeveales or other such lyke playes wherby that eny grete assemble of the kynges people shuld be made had \& caused to be arreysed'. ${ }^{78}$ The ban appears to have been successful as few rewards were made that summer to performers of any type.Various types of performers are associated in these records with towns, and the relationship between their designation and the type of entertainment they performed is ambiguous. However, the various town accounts, particularly the Chamberlains' accounts of Lydd, New Romney, and Rye, Sussex, demonstrate considerable similarities in their designation of the types of performers to whom rewards were paid.

Bann criers and players are the two main types of parish or borough performers noted in these records, and the distinctions made in the records between them are worth tracing. First, the records always associate bann criers with a particular parish or borough while the records associate players variously, with either parishes, boroughs, patrons, or counties. Often the accounts do not note the players' association. Second, bann criers in general receive larger rewards than parish, borough, or unassociated players, and the rewards paid to bann criers are often accompanied by expenses for their entertainment as well. At New Romney, the average total expenditure on bann criers is $12 \mathrm{~s}$ while the average total expense for parish or borough players is $1 \mathrm{~s} 11 \mathrm{~d}$ In Lydd, the averages are $16 \mathrm{~s} 7 \mathrm{~d}$ and $1 \mathrm{~s} 5 \mathrm{~d}$, and at Rye $7 \mathrm{~s} 4 \mathrm{~d}$ and $1 \mathrm{~s}$ $10 \mathrm{~d}$. At Dover, however, the opposite appears to be the case, with an average of $2 \mathrm{~s} 2 \mathrm{~d}$ paid to bann criers and $3 \mathrm{~s} 2 \mathrm{~d}$ paid to parish or borough players. ${ }^{79}$ The amounts paid to bann criers (as discussed above) appear to have been customary amounts with lengthy histories and furthermore these customary amounts were collected by bann criers and passed along by them to the chamberlains as funds sponsoring plays or 'ludi'. In general, these towns' chamberlains appear to have paid more when bann criers performed than when parish or borough players performed. Often these payments included expenditures on entertainment for the bann criers, and rarely, if ever, for parish or borough players.

As in the Kent towns, in Rye the bann criers received more substantial rewards from the chamberlains than did town players. The most common reward paid by the Rye chamberlains to bann criers was $6 s 8 \mathrm{~d}$, and the average 
total expense to bann criers, including expenses on their food and drink, was 7s 6d. In addition, the Rye Chamberlains' accounts often record additional payments for the entertainment of bann criers. Of the seventeen appearances of bann criers in the Rye accounts, nine are accompanied by expenditures for the bann criers' entertainment. ${ }^{80}$

Payments to parish or borough players were substantially lower, with the chamberlains spending, on average, $2 \mathrm{~s} 1 \mathrm{~d}$ in reward and expenses on parish or borough players. Of the fifty rewards paid to town players, on the other hand, only three are accompanied by expenses for the parish or borough players' entertainment. ${ }^{81}$ The average payment to unassociated players was $2 \mathrm{~s} 1 / 2 \mathrm{~d}$.

The Rye Chamberlains' accounts provide valuable information regarding the distinction between bann criers and the entertainers associated with towns which are designated in the Rye Chamberlains' accounts as 'players.' A seasonal distinction apparently defines the two types of entertainer. Thirteen of the seventeen rewards to bann criers appear among those recorded during the Easter quarters (between Easter and 24 June), and another reward can be dated to May $1560 .{ }^{82}$ The remaining three rewards appear in the Midsummer quarters (between 24 June and 24 August). ${ }^{83}$ On the other hand, the majority of the fifty rewards paid to parish or borough players by the Rye chamberlains are recorded in the Bartholomew (between 24 August and 25 December) and Christmas (between 25 December and Easter) quarters, with twenty-one and seventeen rewards recorded respectively in each. Four of these payments are noted for performances during Christmas or Candlemas. ${ }^{84}$ Nine are recorded in the Easter quarters and but two occur in the Midsummer quarters. This trend holds true as well for unassociated players. Of the twenty-two payments to unassociated players, only three were not recorded in the Bartholomew or Christmas quarters, and the date of entry for one record is undeterminable. ${ }^{85}$ Six of these performances are identified as having occurred either at Christmas or at Candlemas. ${ }^{86}$

Similar distinctions can be made for those players rewarded at Rye who were associated with patrons. Of these patronized performers, minstrels tend to be rewarded evenly throughout the Easter (thirty-two rewards), Midsummer (thirty-one), and Bartholomew (thirty) quarters at Rye. However, the number of rewards given to patronized minstrels during the Christmas quarters (seventeen) is just over half that of any of the other quarters. As for patronized players, seventeen rewards are concentrated in the Christmas quarters, although ten rewards appear in the Bartholomew quarters and seven in the Easter. Only three appear in the Midsummer quarters. The average reward 
paid to patronized minstrels at Rye was 4s. while, on average, patronized players received $7 \mathrm{~s} 3 \mathrm{~d}$. But the entries noting rewards paid to patronized minstrels are accompanied nearly a third of the time by entries noting expenses for the food and or drink for the minstrels. Such accompanying expenses are noted only twice in the Rye Chamberlains' accounts for patronized players.

Despite its extent, parish and borough 'ludi' declined drastically in the 1530s, and James Gibson argues that in 1535 this ludic activity abruptly ceases. As the graphs below show, the activity of bann criers and parish or borough players does decline dramatically in the period 1531-5. Yet this activity appears to have been in decline in advance of 1535. In Lydd, for instance (see figure 1), the number of rewards paid to bann criers and parish players declines significantly from it height in 1515-20. While the height of bann crier and parish player at New Romney occurred in 1511-15, bann crier and parish player rewards almost vanish in 1521-31 (see figure 2). Yet in 1526-30, this decline is made up for by the increased number of rewards paid to borough waits, minstrels and other ludic performers. In 1531-5, the number of New Romney chamberlains' rewards to bann criers and parish players reaches its height. While bann criers and parish players practically disappear from New Romney's accounts after 1535, other borough and parish performers fill the gap. Yet after 1540, there is very little parish or borough entertainment activity of any kind.

Due to the large numbers of performers rewarded by the Rye chamberlains, the situation in Rye offers the most detail. While bann criers reach their height in 1516-20, parish or borough players did so in 1521-5 (see figure 3). The appearance of both types of performer declined after that, with but one bann crier appearing there in 1536-40. Rewards to bann criers and parish players do not appear in any significant numbers in the Dover Chamberlains' accounts. Waits and minstrels appear much more frequently. Nevertheless, the decline in bann criers and parish players is evident there, too (see figure 4).

In these towns' accounts, rewards to patronized performers occur alongside those made to parish performers. The patterns of the rewards made to these patronized performers also undergoes a transformation in the mid1530s, with the number of rewards paid to patronized minstrels decreasing and those made to patronized players rising dramatically (see figures 5-8). In all four towns under consideration here, this occurs during the 1536-40 period. Also during this period, the number of rewards paid to patronized performers surpasses the number of rewards paid to parish performers. Dover 
is the exception, but even there the number of patronized performers begins to rise sharply in the 1536-40 period.

In general, the four towns' witnessed a decline in the number of performances by parish performers. Coinciding with this decline was a general rise in the number of performances offered by patronized performers in the decade beginning in 1525 (see figures 9-12). By 1535 in Lydd as well as Rye and by 1540 in New Romney, the number of performances by patronized performers was greater than - and would not again fall below - the number of performances by parish performers. What is striking about this is that during this period the number of performances by patronized minstrels fell while the number of performances by patronized players rose.

While it is by no means certain that the increased performances by patronized players were of plays, the shift from performances by patronized minstrels to performances by patronized players suggests an increase in the frequency with which plays were performed. First, the coincidence of the shift in all four towns suggests that the designation of the performers was relatively consistent across the region. In all four towns there appears to have been a coherent and consistent recognition of the type of performer or performance which warranted the designation of minstrel or player. Second, several of the troupes of players which appear during 1536-40 share patrons with already touring minstrels, and the four towns' account differentiate between a patron's minstrels and players. While a few entries suggest some ambiguity in the designation of the troupes, the bulk of the entries suggest that the designation of performers relied on a locally consistent designation.

In 1535-6, for example, the King's players received rewards from Dover, Rye, and Lydd while the Lord Warden's players received rewards from all four towns. ${ }^{87}$ In 1537-8, The Lord Warden's minstrels and players as well as the King's players received separate rewards in Dover, Rye, and Lydd. ${ }^{88}$ The Lord Warden's minstrels and players also performed in Dover, Lydd, New Romney, and Rye in 1538-9. ${ }^{89}$ Likewise, in 1539, the Lord Warden's players and minstrels performed at Lydd, New Romney and Rye. ${ }^{90}$ In 1540-1, the King's minstrels and players performed at all three towns, with performances by the players at Dover on 2 October and at Rye on 5 October. In addition, the Duke of Suffolk's players, the Prince's players, and the Lord Warden's minstrels performed in all four towns.

While possibly some of these references to patronized players designate troupes of musicians, it is unlikely that they all did. Rather, it seems likely that many performances by patronized players were of drama. This shift is 
significant, and it is useful to review the performance patterns of the various performers discussed above.

In summary, then, bann criers typically performed in the late spring and summer, likely in advance of the performances of the parishes' 'ludi'. Parish and borough players, on the other hand, most often performed in the fall and winter, and many of these performances occurred at Christmas. The seasonal timing of these two types of performers suggests at least an implicit coordination of their tours. The different reception of these two types of parish performer by the host town moreover indicates that the bann criers were the more important of the two types of player. The parish players received much less in reward than did the bann criers, and the performances or visits by bann criers were often accompanied by expenditures on food and drink while the performances by the parish players were not. While the rewards paid to both types of parish performer provide evidence of the generation of social capital, the rewards to bann criers appear to have been more important in this regard. These rewards were collected as parish revenue for the purpose of funding a play or 'ludi'.

The touring patterns of the patronized players bear some similarity to those of the parish performers. As the bann criers and parish players implicitly divided the year between them, so did the patronized performers though to a lesser extent. Patronized minstrels toured throughout the year but appeared significantly less often during the Christmas quarters, the quarters during which patronized players appeared most often. Patronized players on average received more in reward than did the patronized minstrels.

The two groups of performers warrant comparison with each other as well. The patronized players in particular bear some striking similarities to the parish performers. First, the average amount of the patronized players' rewards was similar (at least at Rye) to that paid to bann criers. Second, the seasonal performance of both the parish and patronized players appears similar, with both types of player appearing most often during the Bartholomew and Christmas quarters. While both types of player performed to a lesser extent during the Easter quarters, the quarters during which bann criers most often performed, patronized players only began to do so in 1540 . While the number of rewards paid by the Rye chamberlains to patronized players from 1500 to 1539 amounts to only fourteen, strikingly only one of these rewards is recorded in the Midsummer quarters and none are recorded in the Easter quarters. In other words, the Rye chamberlains paid Easter-quarter rewards to players associated with patrons (rather than with boroughs or parishes) only 
after most parish bann criers (only bann criers for New Romney's 1540 play toured by this point) had ceased performing.

Clearly, then, performances by parish performers declined in southwestern Kent, beginning from the late 1520s. The bulk of the performances cease in the late 1530s although New Romney appears to have continued staging — or attempting to stage — its play in the 1540s, 1550s, and 1560s. As the decline of parish performances began prior to the 1530s, it is impossible for the Henrician Reformation to have caused the decline, although the injunctions of 1536 and 1538 perhaps discouraged the reinvigoration of a practice already declining. In any case, the increased performances by patronized players during the 1530s suggests that the decline of parish 'ludi' and plays in Kent was motivated neither by an incipient evangelical anti-theatricalism nor by an official, centralized anti-theatrical policy. At the very least, the generation of associative connections, 'communitas', or social capital among parishes that the contributions to bann criers supported, disappeared.

Two other trends coincided with the decline of parish performances. The number of performances by patronized minstrels declined while the number of performances by patronized players increased through the 1530s, suggesting that during this period patronized entertainment shifted towards the performance of plays. Moreover, patronized players began performing during the Easter quarters only after bann criers had, for the most part, ceased playing. After 1540, then, patronized players took the place of bann criers, certainly in terms of when performances were made.

While New Romney adapted the performance of its play to the context of the Henrician reformation, the towns and parishes to whose plays or 'ludi' New Romney had contributed did not. In part, this can be attributed to the decline in staging these events which began prior to the reformation in the 1530s. While it remains unclear whether the increased number of performances by patronized players caused, was the effect of, or simply coincided with this decline, apparently these players filled the gap left by the demise of parish 'ludi' and plays. 
Figure 1: Parish or Borough Performers at Lydd

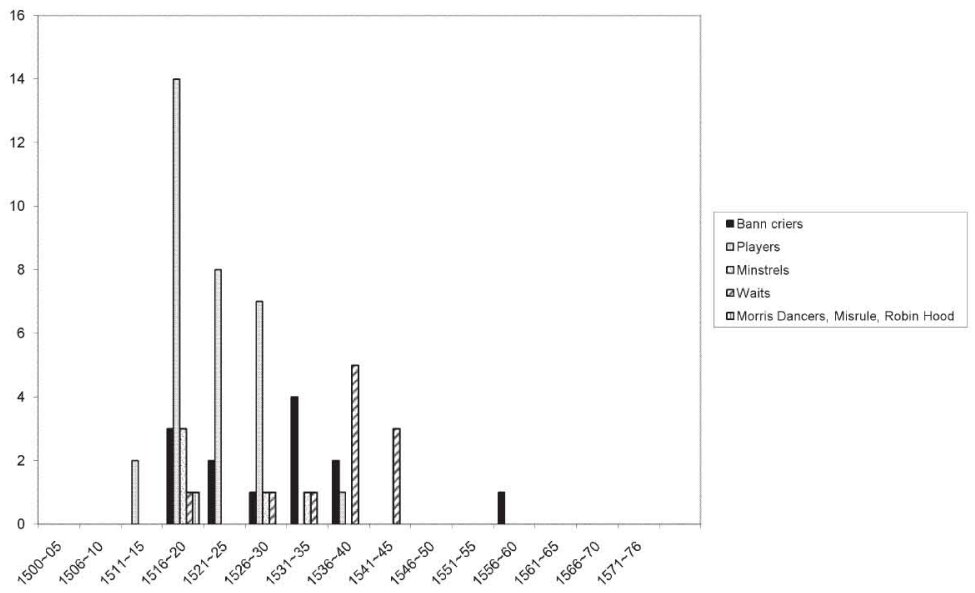

Figure 2: Parish or Borough Performers at New Romney

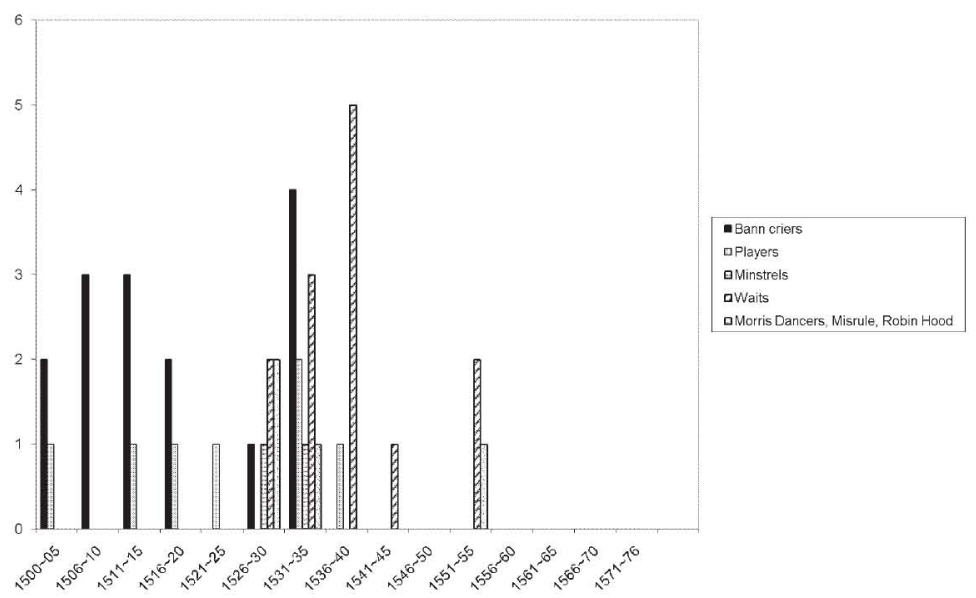


Figure 3: Parish or Borough Performers at Rye

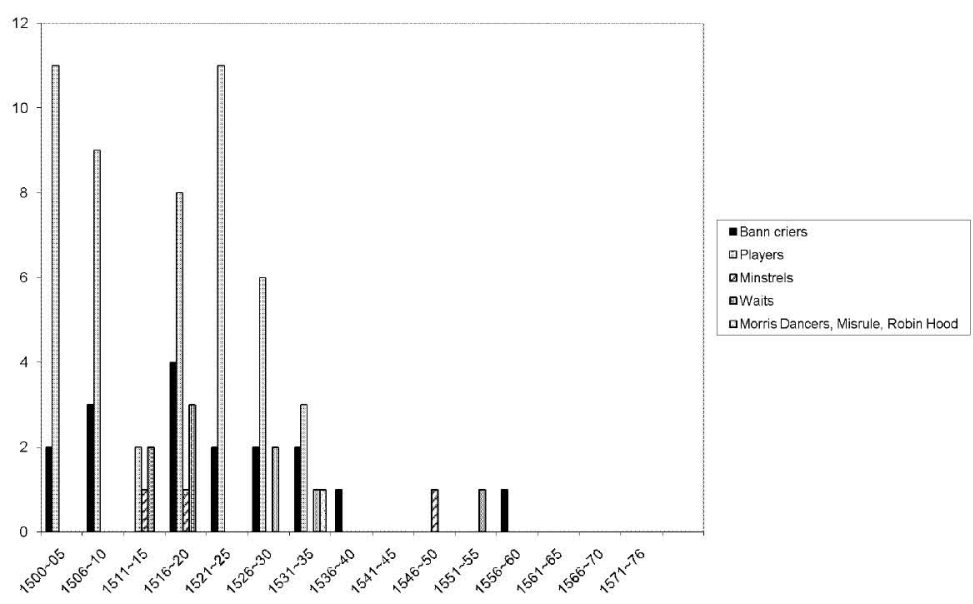

Figure 4: Parish or Borough Performers at Dover

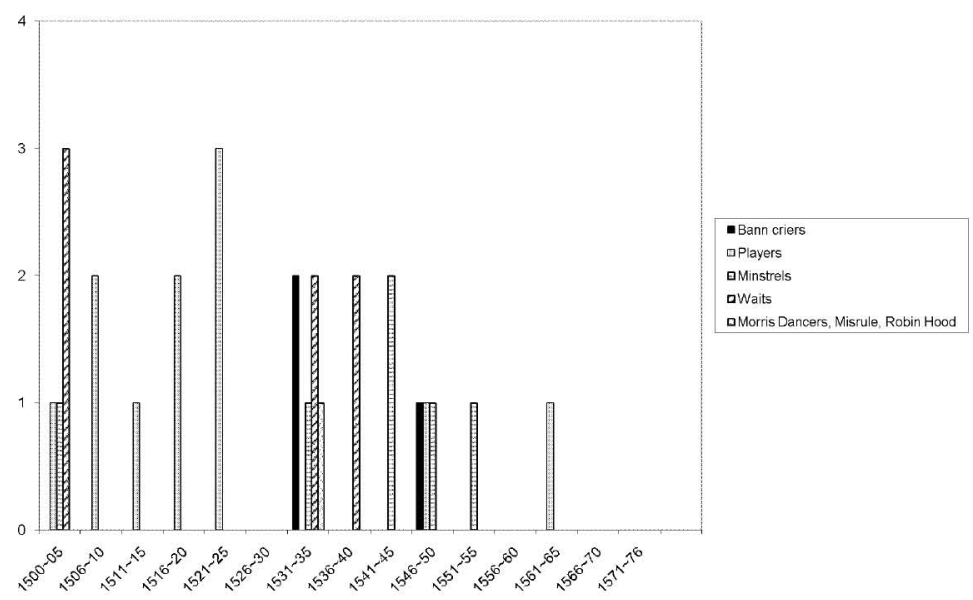


Figure 5: Patronized Performers at Lydd

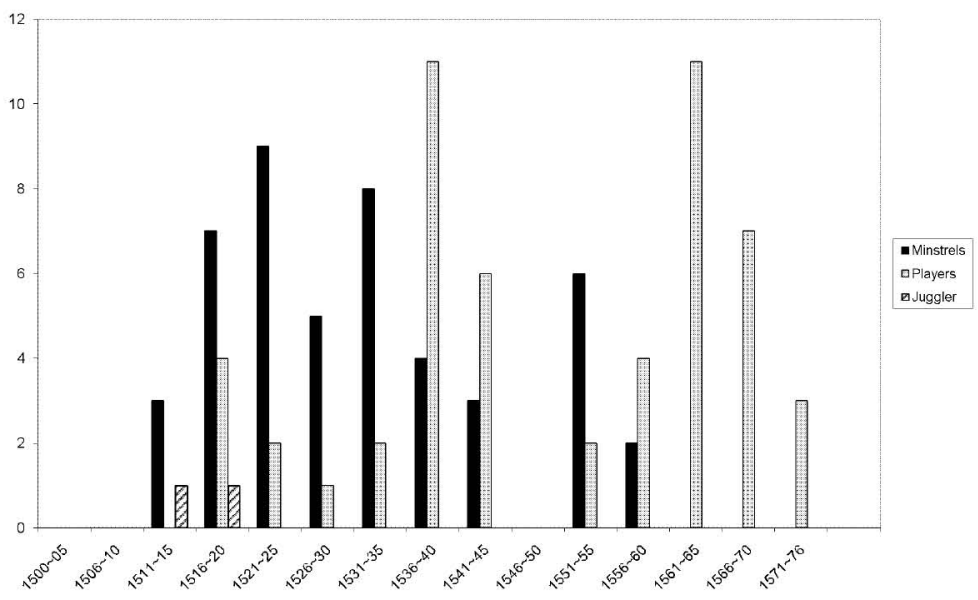

Figure 6: Patronized Performers at New Romney

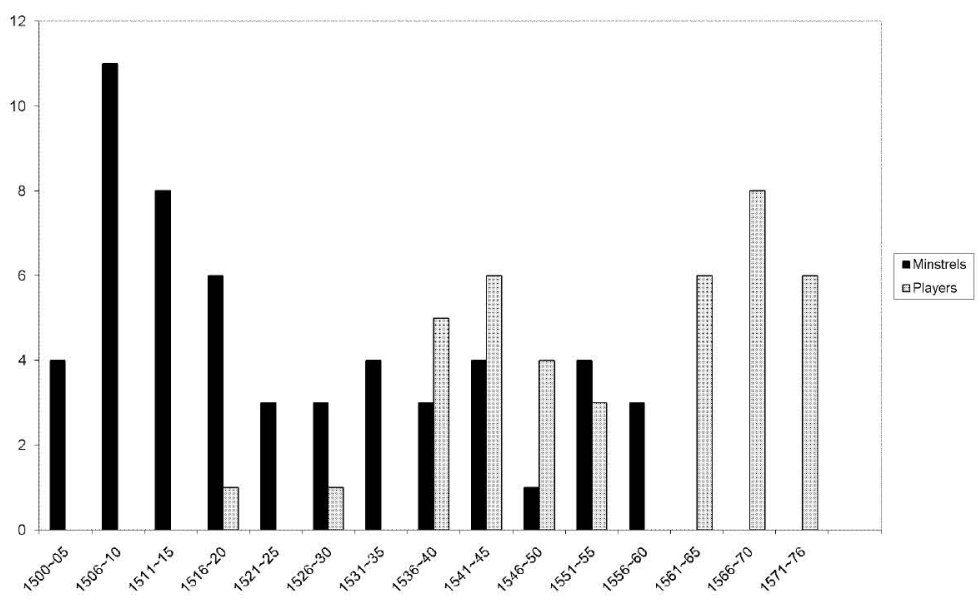




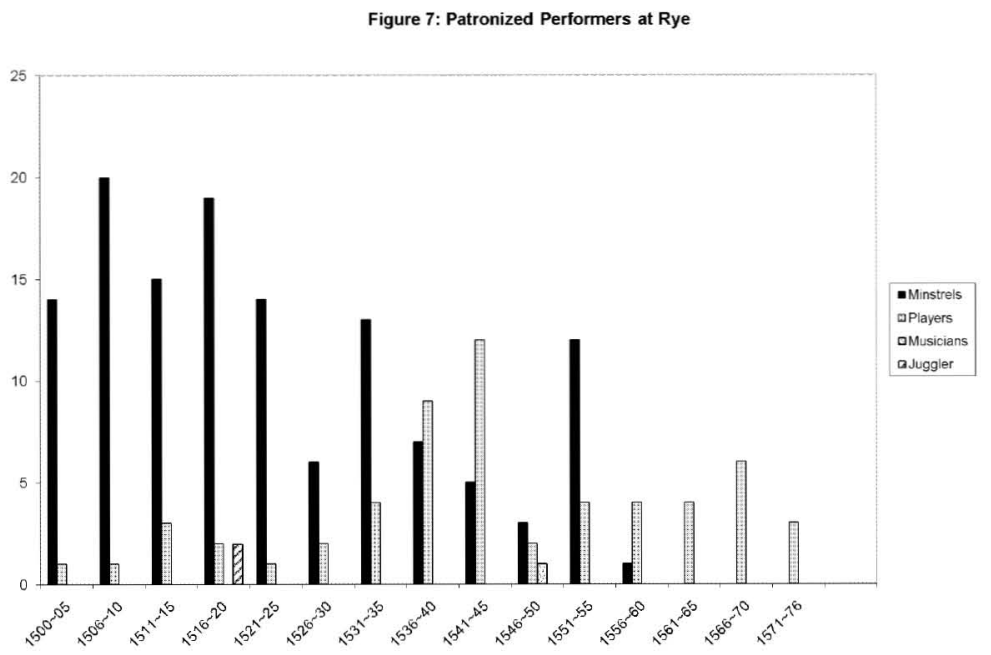

Figure 8: Patronized Performers at Dover

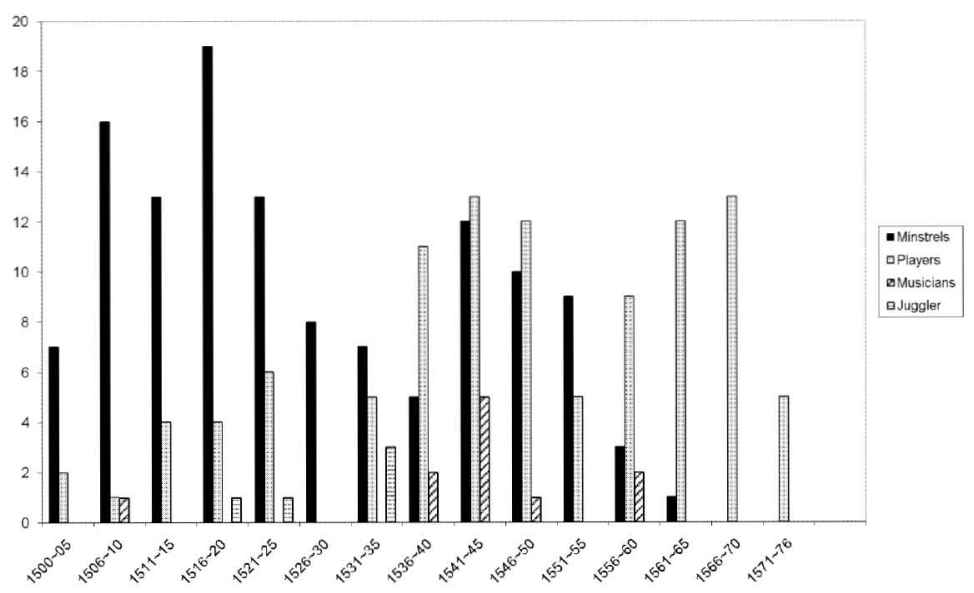


Figure 9: Patronized vs. Parish or Borough Performers at Lydd

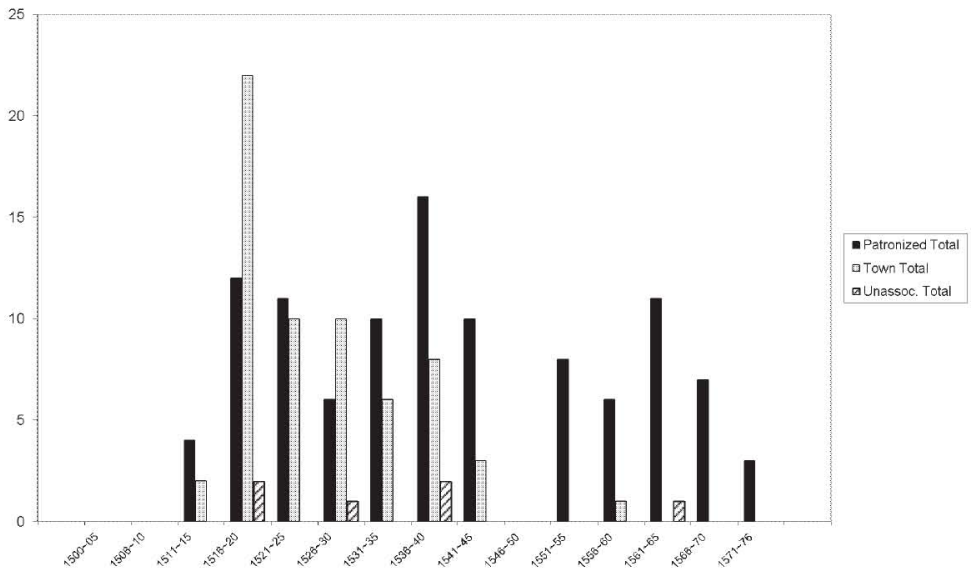

Figure 10: Patronized vs. Parish or Borough Performers at New Romney

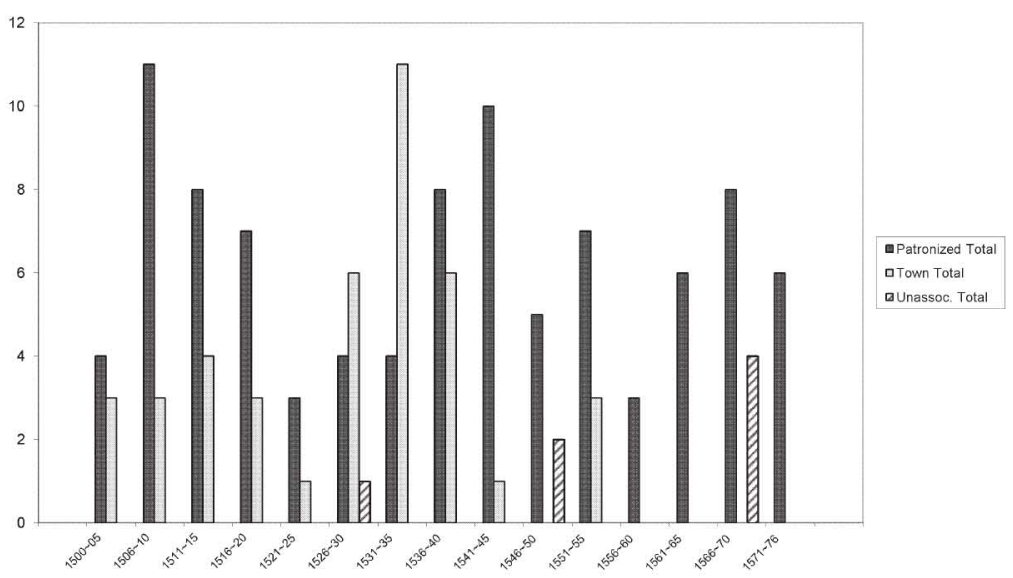


Figure 11: Patronized vs. Parish or Borough Performers at Rye

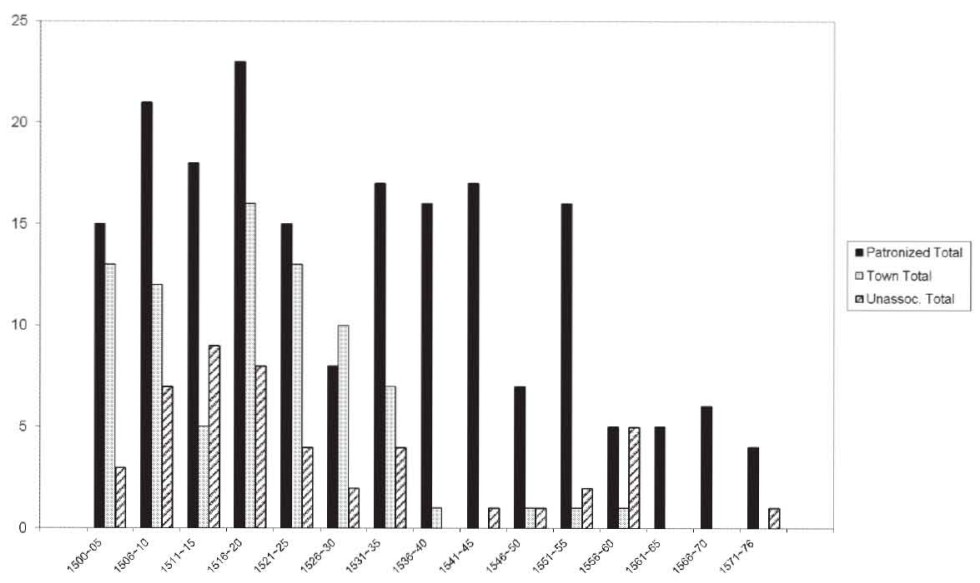

Figure 12: Patronized vs. Parish or Borough Performers at Dover

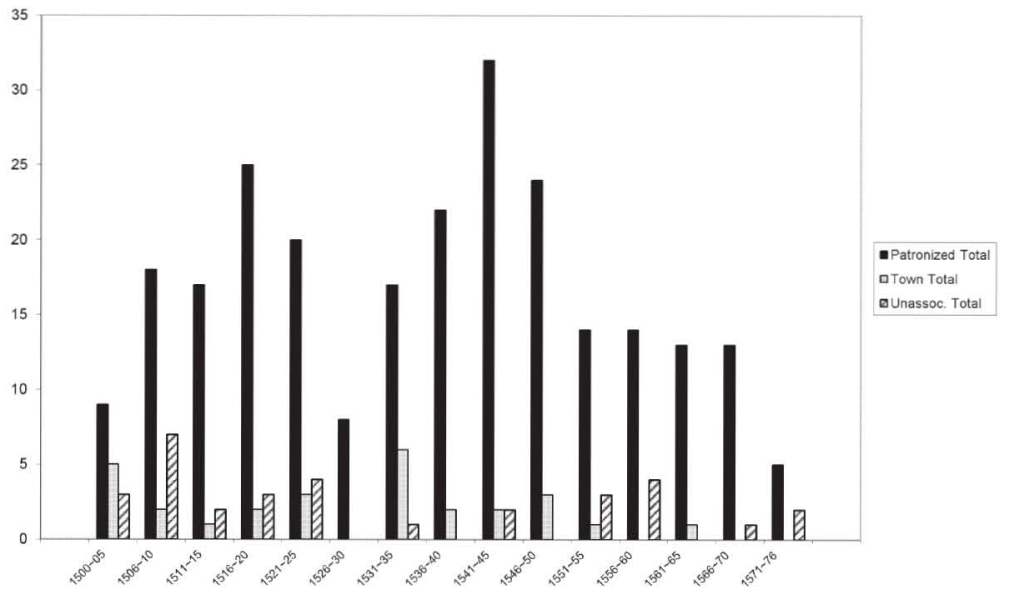




\section{Notes}

I wish to thank Garrett Epp, Jonathan Hart, and the anonymous reviewers of Early Theatre for their comments and assistance with this material. I also would like to thank the Social Sciences and Humanities Research Council and the Killam Trusts for supporting this research.

1 E. K. Chambers, The Mediaeval Stage (1903; Mineola, NY, 1996), 1.109.

2 Ibid.

3 Alexandra F. Johnston, 'Parish Playmaking before the Reformation', The Parish in Late Medieval England: Proceedings of the the 2002 Harlaxton Symposium, Clive Burgess and Eamon Duffy (eds) (Donington, Lincolnshire, 2006), 323.

4 Paul Whitfield White, 'Reforming Mysteries' End: A New Look at Protestant Intervention in English Provincial Drama', Journal of Medieval and Early Modern Studies 29.1 (1999), 140. Also see discussions in Lawrence Clopper, Drama, Play, and Game: English Festive Culture in the Medieval and Early Modern Period, (Chicago, 2001); Glenn Ehrstine, Theater, Culture, and Community in Reformation Bern, 1523-1555, (Boston, 2002); Heather Hill-Vasquez, 'The Possibilities of Performance: A Reformation Sponsorship for the Digby Conversion of Saint Paul', Records of Early English Drama Newsletter 22.1 (1997): 2-20; Jeffrey Leininger, 'Evangelical 'Enterluders': Patronage and Playing in Reformation England', Reformation and Renaissance Review 4.1 (2002): 48-93; John Watkins, 'Bedevilling the Histories of Medieval and Early Modern Drama', Modern Philology 101.1 (2003): 68-78; and Paul Whitfield White, Theatre and Reformation: Protestantism, Patronage and Playing in Tudor England, (Cambridge, 1993).

5 Richard Morison, 'Perswasion to the Kyng That the Laws of the Realme Shuld Be in Latin', Royal MS 18 A.L. British Library, London, 18v.

6 Ibid, 16v-18r.

7 Robert Hornback, 'The Reasons of Misrule Revisited: Evangelical Appropriations of Carnival in Tudor Revels', Early Theatre 10.1 (2007), 37-43.

8 'Letters and Papers: July 1539, 11-15', Letters and Papers, Foreign and Domestic, Henry VIII: 1539. Vol. 14 Part 1 (1894), 554-561, URL: <http://www.british-history.ac.uk/report.aspx?compid=75876>.

9 Alexandra F. Johnston and Sally-Beth Maclean, 'Reformation and Resistance in Thames/Severn Parishes: The Dramatic Witness', The Parish in English Life 14001600, Katherine L. French, Gary G. Gibbs, and Beat A. Kümin (eds) (Manchester, 1997), 181. Johnston and Maclean note that the Easter plays at these parishes 'were recurring events ... while the play is mentioned only once at Henley (1511) and Kingston (1520); all, however, clearly took the Easter celebrations beyond tradition- 


\section{Ernst Gerhardt}

al festive liturgical observances. These four parishes are important witnesses in our growing understanding of the nature of biblical drama in medieval England, since they provide evidence for single episode biblical presentations that contrast with the multi-episode cycles of York, Chester, and Coventry'.

10 James M. Gibson, REED: Kent, Diocese of Canterbury (Toronto, 2002), 1.lvii-lxix. Also see John Wasson, 'The End of an Era: Parish Drama in England from 1520 to the Dissolution', Research Opportunities in Renaissance Drama 31 (1992), 73.

11 Gibson, REED: Kent, 1.lviii-lvix.

12 Wasson, 'The End of an Era', 73. On the lack of evidence of overt Henrician suppression of drama, see Bing D. Bills, 'The 'Suppression Theory' and the English Corpus Christi Play: A Re-Examination', Theatre Journal 32 (1980): 157-68.

13 Clopper, Drama, Play, and Game, 129.

14 Ibid, 125.

15 Ibid, 126.

16 Marjorie K. McIntosh, 'The Diversity of Social Capital in English Communities, 1300-1640 (With a Glance at Modern Nigeria)', Journal of Interdisciplinary History 29.3 (1999), 461 and 464.

17 Ibid, 466.

18 Ibid, 466-7.

19 Ibid, 469 and 488.

20 Ibid, 479-80.

21 Gibson, REED: Kent, 184-7. The narrative below is drawn from Hugh Pilkington's deposition, 187.

22 Lewis Wager, 'The Life and Repentaunce of Mary Magdalene', Reformation Biblical Drama in England: An Old-Spelling Critical Edition. Paul Whitfield White (ed) (New York, 1992), lines 42-50.

23 'The Reynes Extracts', Non-Cycle Plays and Fragments, Norman Davis (ed) (Toronto, 1970), 123.

24 Gibson, REED: Kent, 3.1364.

25 For a discussion of the staging of 'ludi' to raise funds, see Katherine L. French, The People of the Parish: Community Life in a Late Medieval English Diocese, (Philadelphia, 2001), 133; Alexandra F. Johnston, "What Revels Are in Hand?": Dramatic Activities Sponsored by the Parishes of the Thames Valley', English Parish Drama. Alexandra Johnston and Wim Hüsken (eds) (Amsterdam, 1996), 101-2; John C. Coldewey, 'Some Economic Aspects of the Late Medieval Drama', Contexts for Early English Drama, Marianne G. Briscoe and John C. Coldewey (eds) (Bloomington, 1989), 92-5. On parish income in general, see French, People of the Parish, 99-136 and 'To Free Them from Binding: Women in the Late Medieval Parish', Journal of Interdisciplinary History 27 (1996): 387- 
412; Richard Hutton, The Rise and Fall of Merry England, the Ritual Year 1400-1700 (Oxford, 1994), 27-30; and Beat Kümin, The Shaping of a Community: The Rise and Reformation of the English Parish c. 1400-1560 (Aldershot, 1996), 108-25 and 316-17.

26 French, The People of the Parish, 133; James Stokes (ed.), REED: Somerset (Toronto, 1996), 1.126 and 2. 905.

27 French, The People of the Parish, 133; Stokes, REED: Somerset, 1.231. Stokes questions the connection between the money raised at these 'ludi' and the roodloft, 2.927.

28 Johnston, “'What Revels Are at Hand”', 98-100; Johnston and MacLean, 'Reformation and Resistance', 181.

29 Peter H. Greenfield, 'Parish Drama in Four Counties Bordering the Thames Watershed', English Parish Drama, Alexandra F. Johnston and Wim Hüsken (eds) (Amsterdam, 1996), 114.

30 Peter Northeast (ed.), Boxford Churchwardens' Accounts, 1530-1561 (Woodbridge, Suffolk, 1982), xiii and 19-20. The Boxford Churchwardens differentiated the 'profetts of the pley' from money received from other fundraising events and revenues. They received $£ 518$ s 51/2d from 'the gatheryng upon plough munday / the hockpot / the proffyght of iij Alys / \& of the Chirche land'. That they differentiated this money from the money they received from the play suggests that they considered the play to be of a different nature from the Plough Monday festivities, the ales, and the hockpot. The hiring of a property player suggests the event was a play.

31 Anne L. Brannen, 'Parish Play Accounts in Context: Interpreting the Bassingbourn St George Play', Research Opportunities in Renaissance Drama 35 (1996), 56 and 59.

32 Coldewey, 'Some Economic', 92; James Stokes and Stephen K. Wright, 'The Donington Cast List: Innovation and Tradition in Parish Guild Drama in Early Elizabethan Lincolnshire', Early Theatre 2 (1999), 63-64 and 95n38. The evidence for this fundraising is, according to Stokes and Wright, 'cryptic': a note on the Donington cast list reads, 'buttfenndyke for ffynding of'.

33 John C. Coldewey, 'The Digby Plays and the Chelmsford Records', Research Opportunities in Renaissance Drama 8 (1976), 104 and 108-9.

34 Greenfield, 'Parish Drama', 116; Kümin, The Shaping of a Community, 26n85.

35 Northeast, Boxford Churchwardens'Accounts, 19-20, 26, and 30.

36 Coldewey, 'Some Economic', 93-5.

37 Robert Wright, 'Community Theater in Late Medieval East Anglia', Theatre Notebook 28.1 (1974), 34 and 37. For a discussion of 'hub-networks' in which several proximate towns took turns staging plays, the scripts of which were derived from a shared playtext housed at a central hub, likely a monastery, see Douglas Sugano, "“This Game Wel Pleyd in Good a-Ray": The N-Town Playbooks and East Anglian Games', Comparitive Drama 28.2 (1994): 221-34. Sugano suggests that the N-town 
manuscript (and possibly the Towneley manuscript) is an example of such a playtext. See also Gail McMurray Gibson, Theater of Devotion: East Anglian Drama and Society in the Late Middle Ages (Chicago, 1989); Victor Scherb, Staging Faith: East Anglian Drama in the Later Middle Ages (Cranbury, NJ, 2001); and Martin Stevens and A.C. Cawley (eds), The Townley Plays (Oxford, 1994). On the N-Town plays as a compilation rather than a cycle, see Johnston, 'Parish Playmaking', 324.

38 Coldewey, 'Some Economic', 94; Wright, 'Community Theater', 30. Wright lists twenty-six contributing communities, including Dunmow Priory.

39 Brannen, 'Parish Play Accounts', 56.

40 Coldewey, 'Some Economic', 94; W. A. Mepham, 'Mediaeval Plays in the 16th Century at Heybridge and Braintree', Essex Review 55 (1946), 9-10.

41 Northeast, Boxford Churchwardens' Accounts, 18-19.

42 Diarmaid MacCulloch, Suffolk and the Tudors: Politics and Religion in an English County 1500-1600 (Oxford, 1986), 141.

43 Wright, 'Community Theater', 34; Northeast, Boxford Churchwardens' Accounts, 2 and 11 .

44 Johnston, 'Parish Playmaking', 326; McIntosh, 'The Diversity of Social Capital', 463.

45 Northeast, Boxford Churchwardens'Accounts, 19.

46 Johnston, 'Parish Playmaking', 326; James M. Gibson and Isobel Harvey, 'A Sociological Study of the New Romney Passion Play', Research Opportunies in Renaissance Drama 39 (2000), 216.

47 Gibson and Harvey, 'A Sociological Study', 206-14.

48 Gibson, REED: Kent, 1.cxlviii; Cameron Louis (ed.), REED: Sussex (Toronto, 2000), lxviii.

49 Gibson, REED: Kent, 1.9-11.

50 Ibid, 2.675, 2.678, and 2.760; Louis, REED: Sussex, 76.

51 Gibson, REED: Kent 1.18 and 3.1261n 18.

52 Ibid, 2.660.

53 Louis, REED: Sussex, 46; Gibson, REED: Kent, 2.737.

54 Gibson, REED: Kent, 2.678.

55 Ibid, 2.682-7.

56 For discussions of the play, see Clopper, Drama, Play, and Game, 114-18; Gibson and Harvey, 'A Sociological Study', and James M. Gibson, "Interludum Passionis Domini: Parish Drama in Medieval New Romney', English Parish Drama, Alexandra F. Johnston and Wim Hüsken (eds) (Amsterdam, 1996), 137-48.

57 Gibson, REED: Kent, 2.737.

58 Ibid, 2.745-50. 
59 Ibid, 2.755.

60 Ibid, 2.765.

61 Louis, REED: Sussex, 88; Gibson, REED: Kent, 2.674. The Lydd entry falls between 25 March 1516 and 25 March 1517.

62 Gibson, REED: Kent, 2.778-82.

63 Ibid, 2.783-94 and 3.1364.

64 Ibid, 2.798.

65 Ibid, 2.748.

66 However, the Hythe Town accounts record a reward to the Brookland players between 2 February 1505 and 2 February 1506. See Gibson, REED: Kent, 2.627.

67 Louis, REED: Sussex, 80; Gibson, REED: Kent, 2.762. While the Rye accounts indicate that it was New Romney players who were rewarded in 1511, the timing, the amount of the reward, and the payment of expenses to entertain the players are characteristic of rewards made to bann criers. See the discussion below.

68 Gibson, REED: Kent, 2.399.

69 Ibid, 2.676, 2.766, 2.767, 2.768, 2.688, and 2.771; Louis, REED: Sussex, 91, 92, 98, and 103.

70 Gibson, REED: Kent, 2.675 and 2.677; Louis, REED: Sussex, 89.

71 Ibid, 2.676, 2.678, 2.688, 2.759, 2.762, and 2.788. The Hythe Town accounts report a 5 s. reward paid to Brookland bann criers in 1494-95 (Gibson, REED: Kent, 2.623).

72 Ibid, 2.757, 2.760, 2.762, 2.770, and 2.771 .

73 Ibid, 2.399.

74 Ibid, 2.646, 2.647, 2.648, 2.652, 2.656, 2.659, 2.663, 2.664, 2.668, 2.670, 2.674, $2.681,2.687,2.692$, and 2.696 .

75 Ibid, 2.623 and 2.626 .

76 Ibid, 2.696 and 2.790 .

77 Ibid, 1.ccxxiii-ccxxiv.

78 Ibid, 2.427.

79 There is one expense for 3s.10d in the 1547-8 Dover Chamberlains' accounts for 'the drykyng of the men of Romeye at the bannes' and another for 10s. 'to the players of Romney' (Gibson, REED: Kent, 2.448). If these players are assumed to be the apparent bann criers of the drinking entry, then the average expenses regarding bann criers at Dover is $5 \mathrm{~s} .6 \mathrm{~d}$. and the average expense for players is $3 \mathrm{~s} 2 \mathrm{~d}$. Only three rewards to bann criers and eleven to parish or borough players appear in the Dover accounts.

80 Louis, REED: Sussex, 71, 78, 88, 91, 100, 103, 106, and 117.

$81 \mathrm{Ibid}, 79,80$, and 101. However, these three payments for parish players' entertainment display characteristics very similar to the payments to bann criers. The payments 
were to players from New Romney in 1510, Brookland in 1511, and Lydd in 1532, three towns especially active in employing bann criers in other years, and all three payments can be dated to the Easter or Midsummer quarters (Ibid, 79, 80, and 101). Each troupe received the customary bann crier reward of 6s. 8d., and the Brookland bann criers received rewards and entertainment in New Romney and Dover in 1511, and the Lydd bann criers in those years in other towns (suggesting that these players might be bann criers received the customary 6s. 8d. in New Romney in 1532-33, in addition to entertainment). See Gibson, REED: Kent, 2.399, 2.762, and 2.770.

82 Louis, REED: Sussex, 71, 74, 76, 88, 91-93, 96, 98, 100, 103, 106, 117, and 277. While the entries are recorded during these quarters, in at least one case the bann criers may have performed later: an entry notes that the reward was for a performance on Holy Rood Day (Ibid, 88).

83 Ibid, 71, 78, and 91.

84 Ibid, 75, 76, 80, and 102.

85 Ibid, 70, 72, 78, 79, 83-88, 92, 95, 96, 99-101, and 107.

86 Ibid, 70, 72, 74, 84, 87, 94, and 100 .

87 The rewards to the King's players by the Dover Wardens and the Rye chamberlains may be to different troupes as the Dover accounts date the reward to 9 October 1535 and the Rye accounts to 10 October 1535. The Lord Warden's players received a reward from the Dover Wardens on 19 January 1538 and from the Rye chamberlains on 2 February 1536. See Gibson, REED: Kent, 2.433 and Louis REED: Sussex, 104.

88 The Rye chamberlains rewarded the Lord Warden's players on 15 May 1538 and his minstrels on 29 May 1538. The Dover Wardens' accounts date the reward to the King's players to 24 August 1538. As the Lydd Chamberlains' accounts begin and end on 25 March, and rewards to these performers appear in the Lydd accounts during the 1538-39 year, the accounting year which would include May and August 1538. See Louis REED: Sussex, 105 and Gibson, REED: Kent, 2.437 and 2.691.

89 The Dover Wardens' accounts date the Lord Warden's players' performance to 8 February 1539, the New Romney Chamberlains' accounts to 2 February 1539, and the Rye accounts to 3 February 1539. The Lord Warden's minstrels performed at Dover on 31 March 1539 and in Rye between Christmas and 6 April 1539. See Gibson, REED: Kent, 2.438 and 2.772 and Louis REED: Sussex, 105.

90 The Rye accounts date the Lord Warden's minstrels' performance to 12 May 1539. The corresponding entry in the Lydd accounts is during the town's 1539-40 accounts. The Lord Warden's players performed at Rye on 8 April 1540, and likely performed at Lydd shortly before. See Louis REED: Sussex, 106 and Gibson, REED: Kent, 2.691-2. 